\title{
CLONAL BAMBOO PRODUCTION BASED ON in vitro CULTURE
}

\section{PRODUÇÃO DE PLANTAS CLONAIS DE BAMBU A PARTIR DO CULTIVO in vitro}

\section{Anatálya dos Santos RIBEIRO ${ }^{1}$; Alexssandra Jéssica Rondon de FIGUEIREDO ${ }^{1}$; Gabriela Cristina Rech TORMEN ${ }^{1}$; André Luís Lopes da SILVA ${ }^{2}$; Wellington Ferreira CAMPOS ${ }^{3}$; Gilvano Ebling BRONDANI ${ }^{4}$}

1. Federal University of Mato Grosso, College of Forestry, Cuiabá, MT, Brazil. 2. State University of Bahia, Department of Technology and Social Sciences, Juazeiro, BA, Brazil. 3. Federal University of Jequitinhonha and Mucuri Valleys, Institute of Agricultural Sciences, Unaí, MG, Brazil. 4. Federal University of Lavras, Department of Forestry Sciences, Lavras, MG, Brazil. gilvano.brondani@ufla.br

\begin{abstract}
Bamboo species are an alternative for the composition of forest plantations. However, their potential has not been explored due to the hard time in producing large-scale clonal plants. Thus, the aim this work was to evaluate the in vitro establishment, bud multiplication and ex vitro rooting of Bambusa vulgaris. The first experiment tested different systemic and contact fungicide solutions, based on exposure time, during the establishment phase. Established explants were subjected to evaluation of residual fungicide effect on subcultures during the multiplication and elongation phases. The second experiment evaluated the influence of activated carbon on ex vitro survival and on adventitious rooting. Explant immersion in liquid culture medium added with $1.0 \mathrm{~mL}$ of fungicide for 120 hours has favored the in vitro establishment and reduced fungal contamination. On the other hand, it favored the shoot emission of shoots per explant during the multiplication phase. Both rooting induction culture medium and mini-incubator system use were effective in enabling adventitious root formation. The presence of activated carbon in the rooting induction culture medium resulted in a higher clonal plant survival rate.
\end{abstract}

KEYWORDS: Bambusa vulgaris. Cloning. In vitro establishment. Micropropagation. Multiplication. Adventitious rooting.

\section{INTRODUCTION}

Bamboo species are a perennial, renewable and fast-growing resource that presents high yield per field, low cost and diverse use, besides being considered carbon accumulators (CALEGARI et al., 2007; GUIMARÃES JÚNIOR; NOVACK; BOTARO, 2010). Given their high regrowth capacity, they do not require constant replanting in explored fields and can be grown in eroded soils (DA MOTA et al., 2017). Such features turn bamboo plants into an alternative to meet the growing global demand for forest products.

Bambusa vulgaris Schrad ex Wendl is the most common bamboo species distributed in the Brazilian territory (DO VALE; MOREIRA; MARTINS, 2017). This species has been used for ecological applications such as recovering of degraded soils; as well as in industrial applications such as alcohol, cellulose and paper production; and in the manufacture of handicrafts, furniture, fences and scaffolding (GUIMARÃES JÚNIOR; NOVACK; BOTARO, 2010; LIMA NETO et al., 2010). Bamboo species have potential for carbon sequestration and stand out as one of the main nontimber products (MOGNON et al., 2017). Such features translate into great economic potential and income source for farming families (AFONSO; SILVA, 2017). However, according to Mendes et al. (2010), in homogeneous bamboo plantations present high plant density with low rotation and no replanting, a fact that affects the nutritional aspects of crop fertilization, with emphasis on potassium, which is the most exported nutrient.

$B$. vulgaris is a monocarpic species, whose flowering and fruiting take long periods of time; besides, it presents low seed germination rate (most of them are sterile), a fact that makes it unfeasible producing seedlings by sexual reproduction (SINGH et al., 2012a; SANDHU; WANI; JIMÉNEZ, 2018). Therefore, despite its potential, species B. vulgaris has not been extensively grown in Brazil due to the hard time producing large-scale clonal plants.

Micropropagation technique is an alternative to enable mass plant production, since it reduces time and physical space, and enables increased control over propagated material health and genotype reproduction (ERIG; SCHUCH, 2005). Thus, this technique can be used to get clonal plants from matrices, such as $B$. vulgaris species, that face propagation difficulties through other methods. However, microorganism contamination and adventitious root formation in Bambusa vulgaris are the main limiting factors of in vitro 
Clonal bamboo...

establishment and rooting stages, respectively (GARCÍA-RAMÍREZ et al., 2010; MUDOI; SAIKIA; BORTHAKUR, 2014; TORRES; HOULLOU; DE SOUZA, 2016a; TORRES; LEMOS, 2017). Thus, different strategies such as in vitro establishment in different seasons (GARCÍARAMÍREZ et al., 2010; SANDHU; WANI; JIMÉNEZ, 2018), use of chemicals to reduce fungal and bacterial contamination under in vitro conditions (GARCÍA-RAMÍREZ et al., 2007; TORRES; HOULLOU; DE SOUZA, 2016a; BRONDANI et al., 2017; TORRES; LEMOS, 2017; FURLAN et al., 2018), search for adequate concentrations of auxins, cytokinins and other plant growth regulators capable of increasing shoot multiplication and adventitious rooting (NDIAYE et al., 2006; RAMÍREZ et al., 2012; MALINI; ANANDAKUMAR, 2013), as well as the use of bioreactors (RIBEIRO et al., 2016) have been adopted to develop a viable protocol for in vitro plant production of $B$. vulgaris. Thus, the aim of the current study was to develop a micropropagation protocol to enable clonal production of $B$. vulgaris plants.

\section{MATERIAL AND METHODS}

\section{Experiment 1 - In vitro establishment and multiplication}

\section{Material collection and preparation}

Shoots were collected from six-year-old Bambusa vulgaris Schrad. ex J. C. Wendl plants in Cuiabá County, Mato Grosso State, Brazil. Shoots presenting dormant buds were washed in distilled
RIBEIRO, A. S. et al.

and autoclaved water added with liquid detergent. Next, shoots were sectioned in the region next to the buds in order to get explants, which consisted of 1.0-to-1.5-cm-long nodal segments, whose leaves were fully removed. The leaf sheath insertion was previously scraped to reduce microorganism contamination (FURLAN et al., 2018; BRONDANI et al., 2017).

\section{In vitro establishment}

Uniform nodal segments (explants) were immersed in hydroalcoholic solution $(70 \%)$ for one minute; next, they were immersed in sodium hypochlorite solution $(\mathrm{NaOCl}, 2.0-2.5 \%$ active chlorine) under constant stirring for 10 minutes. After asepsis, explants were rinsed three times with distilled and autoclaved water and inoculated into glass tubes $(2 \times 10 \mathrm{~cm})$ filed with $2 \mathrm{~mL}$ of MS culture medium (MURASHIGE; SKOOG, 1962). They were grown in incubation room under the following conditions: temperature of $25^{\circ} \mathrm{C}\left( \pm 2^{\circ} \mathrm{C}\right)$, photoperiod of 16 hours and brightness of $32 \mu \mathrm{mol}$ $\mathrm{m}^{-2} \mathrm{~s}^{-1}$.

Two 5,6-dihydro-2-methyl-1,4-oxathie-3carboxanilide (systemic action mode) and tetramethylthiuram disulphide (contact action mode) fungicide concentrations $\left(0.1\right.$ and $\left.0.2 \mathrm{mg} \mathrm{L}^{-1}\right)$ were evaluated in comparison to in vitro establishment, by taking into consideration different explant immersion times (72 and 120 hours); as well as to the control treatment ( 0 hour $)$, which was characterized by the lack of contact between explant and fungicide (Table 1). Fungicides were added to the culture medium prior to autoclaving.

Table 1. Immersion time and fungicide solutions tested during in vitro establishment of Bambusa vulgaris nodal segments.

\begin{tabular}{llll}
\hline \multirow{2}{*}{ Treatment } & \multirow{2}{*}{ Time $^{1}$ (hours) } & Active principle $\left(\mathrm{mg} \mathrm{L}^{-1}\right)$ & \\
\cline { 3 - 4 } & & Systemic fungicide & Contact fungicide \\
\hline T1 $^{2}$ & 0 & 0.1 & 0.1 \\
T2 $^{2}$ & 0 & 0.2 & 0.2 \\
T3 & 72 & 0.1 & 0.1 \\
T4 & 72 & 0.2 & 0.2 \\
T5 & 120 & 0.1 & 0.1 \\
T6 & 120 & 0.2 & 0.2 \\
\hline
\end{tabular}

${ }^{\mathrm{I}}$ Time of explant immersion in liquid culture medium added with fungicide. ${ }^{2}$ Treatments that did not allow contact between explant and fungicide (i.e., control).

Explants were transferred to glass tubes filed with $2 \mathrm{~mL}$ of liquid MS culture medium after the immersion times set for each treatment were over (Table 1). At 14 days, all explants were transferred to glass tubes filed with $5 \mathrm{~mL}$ of semi- solid MS culture medium added with agar $\left(7 \mathrm{~g} \mathrm{~L}^{-1}\right)$ and sucrose $\left(30 \mathrm{~g} \mathrm{~L}^{-1}\right)$ (Figure 1).

The experiment has followed a completely randomized design with factorial arrangement $(3 \times$ 2 ); three times of explant immersion in culture medium and two fungicide concentrations were 
tested (Table 1). Each treatment comprised 40 explants. Contamination (i.e., fungal and bacterial) and oxidation rates were evaluated at the end of the $30^{\text {th }}$ day. Non-contaminated and non-oxidized explants were classified as established.

\section{In vitro multiplication and shoot emission}

Established explants were transferred to MS culture medium supplemented with agar $\left(7 \mathrm{~g} \mathrm{~L}^{-1}\right)$, sucrose (30 $\left.\mathrm{g} \mathrm{L}^{-1}\right)$, benzylaminopurine $\left(3 \mathrm{mg} \mathrm{L}^{-1}\right)$ and naphthaleneacetic acid $\left(0.50 \quad \mathrm{mg} \mathrm{L}^{-1}\right)$. Subcultures were carried out for new culture medium every 30 days by keeping the same medium composition. Shoots larger than $1.5 \mathrm{~cm}$ were sectioned next to the axillary bud and transferred to new glass tubes to enable getting new explants. The number of explants emitting shoots, the number of shoots per explant and the mean shoot length per explant were evaluated in each subculture.

The experiment has followed a completely randomized design with factorial arrangement $(3 \times 2$ $\times 4$ ), three times of explant immersion in culture medium, two fungicide concentrations and four subculture times (0, 30, 60 and 90 days). After the previous stage of the experiment was over, the number of replications was set for each treatment; it ranged from 8 to 28 replications. This variation was taken into consideration in the statistical analysis, based on the application of a mathematical model to different replications.

\section{Experiment 2 - Ex vitro rooting and acclimatization}

\section{Plant material preparation and in vitro establishment}

Shoots were collected from six-year-old $B$. vulgaris plants in Cuiabá County, Mato Grosso State, Brazil. Shoots presenting dormant buds were washed in distilled and autoclaved water added with liquid detergent. Next, shoots were sectioned in the region next to the buds to enable getting the explants, which consisted of 1.0-to-1.5-cm-long nodal segments, whose leaves were fully removed. The leaf sheath insertion was previously scraped (FURLAN et al., 2018; BRONDANI et al., 2017) and the material was immersed in solution comprising distilled water and fungicides such as 5,6-dihydro-2-methyl-1,4-oxati-3-carboxanilide (0.2 $\left.\mathrm{mg} \mathrm{L}^{-1}\right)$ and tetramethylthiuram disulphide $(0.2 \mathrm{mg}$ $\left.\mathrm{L}^{-1}\right)$ for 24 hours. After the exposure time was over, shoots were rinsed with distilled and autoclaved water, and then sectioned in the region close to the buds.
Explants consisted of 1.0-to-1.5-cm-long nodal segments, whose leaves were fully removed. Explants were immersed in hydroalcoholic solution (70\%) for one minute; next, they were immersed in sodium hypochlorite solution $(\mathrm{NaOCl}, 2.0-2.5 \%$ active chlorine) for 10 minutes. After asepsis, explants were rinsed three times with distilled and autoclaved water, and inoculated into glass tubes (2 $\times 10 \mathrm{~cm}$ ) filed with $5 \mathrm{~mL}$ of MS liquid culture medium. They were grown in incubation room at $25^{\circ} \mathrm{C}\left( \pm 2^{\circ} \mathrm{C}\right)$, under 16 -h photoperiod and brightness equal to $32 \mu \mathrm{mol} \mathrm{m} \mathrm{m}^{-2}$.

\section{In vitro multiplication and shoot emission}

Twenty-one-day-old established explants were transferred to MS culture medium supplemented with agar $\left(7 \mathrm{~g} \mathrm{~L}^{-1}\right)$, sucrose $\left(30 \mathrm{~g} \mathrm{~L}^{-1}\right)$, benzylaminopurine $\quad\left(3 \quad \mathrm{mg} \quad \mathrm{L}^{-1}\right)$ and naphthaleneacetic acid $\left(0.50 \mathrm{mg} \mathrm{L}^{-1}\right)$ in order to enable shoot multiplication and elongation. After 30 days, explants showing shoots larger than $2 \mathrm{~cm}$ were transferred to rooting induction medium.

\section{Ex vitro rooting and acclimatization}

After multiplication phase and shoot emission, explants presenting shoots larger than 2 $\mathrm{cm}$ were transferred to rooting induction medium, where they remained for seven days. The culture medium comprised autoclaved distilled water, agar $\left(7 \mathrm{~g} \mathrm{~L}^{-1}\right)$, sucrose $\left(30 \mathrm{~g} \mathrm{~L}^{-1}\right)$, indole-3-butyric acid (1 $\left.\mathrm{mg} \mathrm{L}^{-1}\right)$ and activated charcoal $\left(1 \mathrm{~g} \mathrm{~L}^{-1}\right)$. The control treatment comprised culture medium without activated charcoal. Next, explants were transferred to a mini-incubator system (BRONDANI et al., 2018) (Figure 2), which consisted of a styrofoam tray divided into $9.93-\mathrm{mL}$ cells filled with a mixture of commercial organic substrate based on pinus bark and vermiculite $(1: 1, \mathrm{v} / \mathrm{v})$. The styrofoam tray was covered with plastic bag and placed in a plastic box filed with $10 \mathrm{~mm}$ of water to keep humidity inside it. Explants were grown in incubation room at $25^{\circ} \mathrm{C}$ $\left( \pm 2^{\circ} \mathrm{C}\right)$, under 16 -h photoperiod and brightness equal to $32 \mu \mathrm{mol} \mathrm{m} \mathrm{m}^{-2}$. Root survival rate, rooting, as well as root number and length were evaluated after 45 incubation days in mini-incubator. The experiment has followed a completely randomized design with factorial arrangement. Two activated coal concentrations $\left(0\right.$ and $\left.1 \mathrm{~g} \mathrm{~L}^{-1}\right)$ were tested in the ex vitro rooting of $B$. vulgaris explants. Each treatment comprised 36 explants.

The acclimatization of micropropagated plants was divided in two stages. In the first stage, plants that have survived after 45 days in a miniincubator system were transplanted into plastic cups $(250 \mathrm{~mL})$, where they remained for 30 days in 
environment under controlled temperature, humidity and luminosity conditions. Shoots were covered with transparent plastic cups to avoid mortality caused by too low relative humidity. The coverage was gradually removed (every seven days) over time. In the second stage, plants were transferred to larger plastic cups $(500 \mathrm{~mL})$ and stored in shade house for 30 days ( $50 \%$ shade).

\section{Statistical analysis}

Data measured in all the experiments were subjected to the Shapiro-Wilk's test $(p<0.05)$ and Bartlett's test $(p<0.05)$ in order to verify the normality and homogeneity of the variances, respectively; they were transformed through Box-
Cox whenever necessary. After analysis of variance (ANOVA, $p<0.05$ ) the means were compared through Duncan's test $(p<0.05)$, according to their significance.

\section{RESULTS}

\section{Experiment 1 - In vitro establishment and multiplication}

Microorganisms were observed in all treatments, a fact that evidenced a hard time controlling contamination (Figure 1). However, it was possible obtaining B. vulgaris explants in all fungicide treatments (Figure 2).

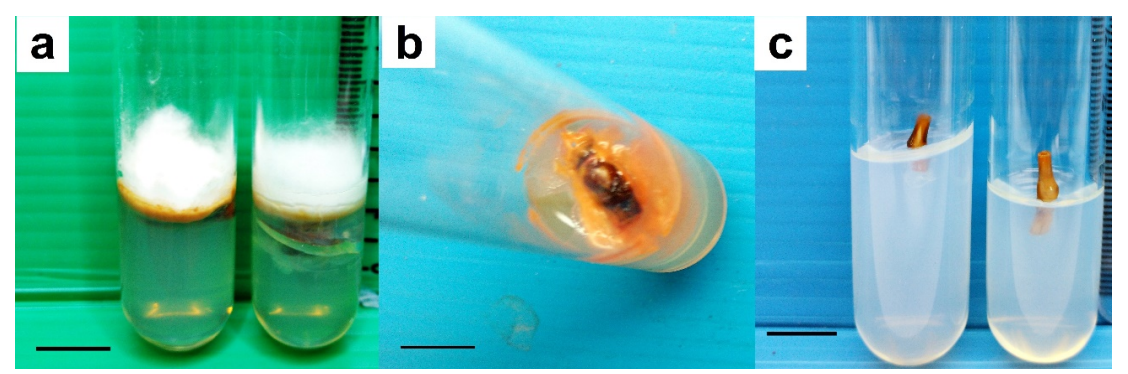

Figure 1. Fungal contamination (a), bacterial contamination (b) and mortality (c) observed in Bambusa vulgaris explants during in vitro establishment $(\mathrm{Bar}=1 \mathrm{~cm})$.

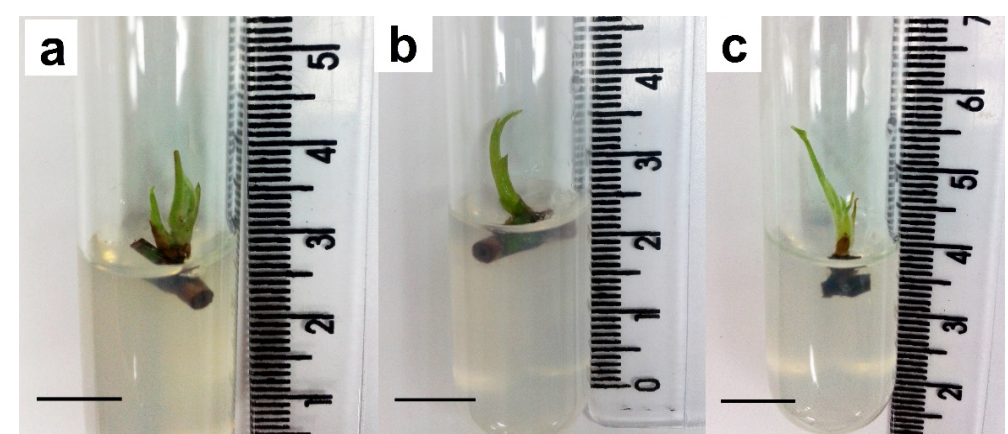

Figure 2. Established Bambusa vulgaris explants.

(a) Control. b) Explants immersed in fungicide for 72 hours. (c) Explants immersed in fungicide in 120 hours $($ Bars $=1 \mathrm{~cm})$.

The fungal contamination of explants immersed in medium added with $0.2 \mathrm{mg} \mathrm{L}^{-1}$ of fungicide for 120 hours was lower than that of the fungicide-free control ( 0 hours). There were no differences in fungal contamination between explants treated with $0.1 \mathrm{mg} \mathrm{L}^{-1}$ of fungicide for 72 or 120 hours (Table 2). Fungal contamination did not show significant interaction between fungicide concentration and immersion time. The fungicide treatment did not inhibit bacterial growth (Table 2). The in vitro establishment of $B$. vulgaris explants was greater in plants treated with $0.2 \mathrm{mg} \mathrm{L}^{-1}$ of fungicide for 120 hours (Table 2). Thus, based on the analyzed data, $B$. vulgaris explant immersion in medium added with $0.2 \mathrm{mg} \mathrm{L}^{-1}$ of fungicide for 120 hours decreased fungal contamination and improved in vitro establishment.

There was not difference in the number of explants emitting shoots and mean number of shoots per explant in plants immersed in medium added with $0.1 \mathrm{mg} \mathrm{L}^{-1}$ of fungicide for 72 or 120 hours. However, the number of explants emitting shoots was larger in plants treated with $0.2 \mathrm{mg} \mathrm{L}^{-1}$ of fungicide for 72 hours (Table 3 ). The mean number of shoots per explant was also larger in explants treated with $0.2 \mathrm{mg} \mathrm{L}^{-1}$ of fungicide for 72 or 120 hours (Table 3). Shoot length in explants treated with 0.1 or $0.2 \mathrm{mg} \mathrm{L}^{-1}$ of fungicide for 72 or 120 hours was longer than that of the fungicide-free control (0 hours) (Table 3). 
Table 2. Percentage of fungal contamination, bacterial contamination, and explants establishment of Bambusa vulgaris regarding treatments at $30^{\text {th }}$ days.

\begin{tabular}{lllll}
\hline Variable & $\begin{array}{l}\text { Immersion } \\
\text { (hours) }\end{array}$ & time & Fungicide $\left(\mathrm{mg} \mathrm{L}^{-1}\right)$ & Mean \\
\cline { 3 - 4 } & 0 & 0.1 & 0.2 & \\
\hline \multirow{3}{*}{ Fungal contamination (\%) } & 72 & $35.00( \pm 7.63)$ & $50.00( \pm 8.00)$ & $42.50^{\mathrm{b}}$ \\
& 120 & $50.00( \pm 8.00)$ & $70.00( \pm 7.33)$ & $60.00^{\mathrm{a}}$ \\
& Mean & $37.50( \pm 7.75)$ & $25.00( \pm 6.93)$ & $31.25^{\mathrm{b}}$ \\
& 0 & 40.83 & 48.33 & 44.58 \\
\hline \multirow{3}{*}{ Bacterial contamination (\%) } & 72 & $40.00^{\mathrm{aA}}( \pm 7.84)$ & $10.00^{\mathrm{aB}}( \pm 4.80)$ & 25.00 \\
& 120 & $22.50^{\mathrm{aA}}( \pm 6.68)$ & $22.50^{\mathrm{aA}}( \pm 6.68)$ & 22.50 \\
& Mean & $25.00^{\mathrm{aA}}( \pm 6.93)$ & $30.00^{\mathrm{aA}}( \pm 7.33)$ & 27.50 \\
& 0 & 29.16 & 20.83 & 25.00 \\
\hline In vitro establishment (\%) & 72 & $65.00^{\mathrm{aA}}( \pm 7.63)$ & $50.00^{\mathrm{aA}}( \pm 8.00)$ & 57.50 \\
& 120 & $50.00^{\mathrm{aA}}( \pm 8.00)$ & $22.50^{\mathrm{bB}}( \pm 6.68)$ & 36.25 \\
& Mean & $47.50^{\mathrm{aA}}( \pm 7.99)$ & $70.00^{\mathrm{aA}}( \pm 7.33)$ & 58.75 \\
& 54.16 & 47.50 & 50.83 \\
\hline
\end{tabular}

${ }^{1}$ Time of explant immersion in liquid culture medium added with two fungicide concentrations. Data were expressed as mean ( \pm SE). Means followed by equal uppercase letters on the line did not statistically differ from each other, whereas means followed by lowercase letters in the same column did not statistically differ from each other, Duncan's test $(p<0.05)$.

Table 3. Percentage of explants emitting shoots, mean number of shoots per explant and mean shoot length of Bambusa vulgaris immersed in culture medium added with two fungicide concentrations for 0,72 and 120 hours.

\begin{tabular}{|c|c|c|c|c|}
\hline \multirow[t]{2}{*}{ Variable } & \multirow{2}{*}{$\begin{array}{l}\text { Immersion } \\
\text { (hours) }^{1}\end{array}$} & \multicolumn{2}{|l|}{ Fungicide $\left(\mathrm{mg} \mathrm{L}^{-1}\right)$} & \multirow[t]{2}{*}{ Mean } \\
\hline & & 0.1 & 0.2 & \\
\hline \multirow{4}{*}{ Explants emitting shoots (\%) } & 0 & $31.08^{\mathrm{aA}}( \pm 10.95)$ & $13.51^{\mathrm{cB}}( \pm 05.52)$ & 22.29 \\
\hline & 72 & $37.03^{\mathrm{aA}}( \pm 12.69)$ & $42.50^{\mathrm{aA}}( \pm 11.37)$ & 39.76 \\
\hline & 120 & $27.45^{\mathrm{aA}}( \pm 12.87)$ & $24.39^{\mathrm{bA}}( \pm 10.19)$ & 25.92 \\
\hline & Mean & 31.85 & 26.80 & 29.32 \\
\hline \multirow{4}{*}{$\begin{array}{l}\text { Mean number of shoots per } \\
\text { explant (shoot explant }{ }^{-1} \text { ) }\end{array}$} & 0 & $1.84^{\mathrm{aA}}( \pm 0.13)$ & $0.26^{\mathrm{bB}}( \pm 0.08)$ & 1.05 \\
\hline & 72 & $1.91^{\mathrm{aA}}( \pm 0.23)$ & $1.71^{\mathrm{aA}}( \pm 0.14)$ & 1.81 \\
\hline & 120 & $2.07^{\mathrm{aA}}( \pm 0.27)$ & $1.95^{\mathrm{aA}}( \pm 0.21)$ & 2.01 \\
\hline & Mean & 1.94 & 1.31 & 1.62 \\
\hline \multirow{4}{*}{$\begin{array}{l}\text { Mean shoot length per explant } \\
\left(\mathrm{cm}^{-} \text {explant }{ }^{-1}\right)\end{array}$} & 0 & $0.79^{\mathrm{bA}}( \pm 0.08)$ & $0.11^{\mathrm{cB}}( \pm 0.04)$ & 0.45 \\
\hline & 72 & $0.97^{\mathrm{abB}}( \pm 0.14)$ & $1.37^{\mathrm{aA}}( \pm 0.11)$ & 1.17 \\
\hline & 120 & $0.99^{\mathrm{aA}}( \pm 0.16)$ & $0.72^{\mathrm{bB}}( \pm 0.10)$ & 0.86 \\
\hline & Mean & 0.92 & 0.74 & 0.83 \\
\hline
\end{tabular}

${ }^{1}$ Time of explant immersion in liquid culture medium added with two fungicide concentrations. Data were expressed as mean ( \pm SE). Means followed by equal uppercase letters on the line did not statistically differ from each other, whereas means followed by lowercase letters in the same column did not statistically differ from each other, Duncan's test $(p<0.05)$.

Explants immersed in culture medium added with fungicide for 120 hours recorded larger number of shoots per explant throughout the subcultures (Table 4). On the other hand, shoot length in explants treated with fungicide for 72 hours was longer than that of the control ( 0 hour) or 120 hours along the subcultures (Table 4). Explants immersed in medium added with 0.1 or $0.2 \mathrm{mg} \mathrm{L}^{-1}$ of fungicide presented similar shoot length throughout the subcultures (Table 5).

\section{Experiment 2 - Ex vitro rooting and acclimatization}

After multiplication phase and shoot emission, explants presenting shoots larger than 2 $\mathrm{cm}$ were transferred to rooting induction medium added with 0 or $1 \mathrm{~g} \mathrm{~L}^{-1}$ of activated charcoal. Next, they were transferred to a mini-incubator system (BRONDANI et al., 2018). Explants immersed in 1 $\mathrm{g} \mathrm{L}^{-1}$ of activated charcoal recorded higher survival rate than the non-treated ones (Table 6). 
Table 4. Mean number of shoots per explant and mean length of shoots of Bambusa vulgaris based on immersion time in culture medium added with fungicide, and on different subcultures.

\begin{tabular}{llllll}
\hline Variable & $\begin{array}{l}\text { Subculture } \\
(\text { days })^{1}\end{array}$ & 0 hours & 72 hours & 120 hours & Mean \\
\hline & 0 & $0.17^{\mathrm{bC}}( \pm 0.10)$ & $1.18^{\mathrm{bB}}( \pm 0.12)$ & $1.60^{\mathrm{bcA}}( \pm 0.40)$ & 0.98 \\
Mean number of & 30 & $0.37^{\mathrm{bB}}( \pm 0.16)$ & $1.31^{\mathrm{bA}}( \pm 0.12)$ & $1.18^{\mathrm{cA}}( \pm 0.13)$ & 0.96 \\
shoots per explant & 60 & $1.64^{\mathrm{B}}( \pm 0.18)$ & $1.99^{\mathrm{aA}}( \pm 0.21)$ & $2.01^{\mathrm{bA}}( \pm 0.27)$ & 1.88 \\
(shoot explant $\left.^{-1}\right)$ & 90 & $1.74^{\mathrm{aC}}( \pm 0.20)$ & $2.37^{\mathrm{aB}}( \pm 0.29)$ & $2.78^{\mathrm{aA}}( \pm 0.29)$ & 2.30 \\
& Mean & 0.98 & 1.71 & 1.89 & 1.53 \\
\hline & 0 & $0.07^{\mathrm{bC}}( \pm 0.04)$ & $1.05^{\mathrm{bcA}}( \pm 0.17)$ & $0.78^{\mathrm{bB}}( \pm 0.17)$ & 0.63 \\
Mean shoot length & 30 & $0.21^{\mathrm{bC}}( \pm 0.09)$ & $1.82^{\mathrm{aA}}( \pm 0.28)$ & $1.20^{\mathrm{aB}}( \pm 0.33)$ & 1.08 \\
per explant $\quad(\mathrm{cm}$ & 60 & $0.61^{\mathrm{aB}}( \pm 0.13)$ & $1.18^{\mathrm{bA}}( \pm 0.13)$ & $0.72^{\mathrm{bB}}( \pm 0.12)$ & 0.84 \\
explant & & $0.74^{\mathrm{BB}}( \pm 0.07)$ & $0.94^{\mathrm{cA}}( \pm 0.08)$ & $0.73^{\mathrm{bB}}( \pm 0.07)$ & 0.80 \\
& 90 & $0.41^{-1}$ & 1.25 & 0.85 & 0.83 \\
\hline
\end{tabular}

${ }^{1}$ Subculture and time of explant immersion in liquid culture medium. Data were expressed as mean ( \pm SE). Means followed by equal uppercase letters on the line did not statistically differ from each other, whereas means followed by lowercase letters in the same column did not statistically differ from each other, Duncan's test $(p<0.05)$.

Table 5. Average length of shoots of Bambusa vulgaris in relation to two concentrations of fungicide along different subcultures.

\begin{tabular}{|c|c|c|c|}
\hline \multirow{2}{*}{ Subculture (days) ${ }^{1}$} & \multicolumn{2}{|c|}{ Fungicide $\left(\mathrm{mg} \mathrm{L}^{-1}\right)$} & \multirow{2}{*}{ Mean } \\
\hline & 0.1 & 0.2 & \\
\hline 0 & $0.78^{\mathrm{bA}}( \pm 0.10)$ & $0.35^{\mathrm{cB}}( \pm 0.10)$ & 0.57 \\
\hline 30 & $1.25^{\mathrm{aA}}( \pm 0.28)$ & $0.65^{\mathrm{bB}}( \pm 0.17)$ & 0.95 \\
\hline 60 & $0.85^{\mathrm{bA}}( \pm 0.11)$ & $0.93^{\mathrm{aA}}( \pm 0.13)$ & 0.89 \\
\hline 90 & $0.81^{\mathrm{bA}}( \pm 0.04)$ & $0.81^{\mathrm{abA}}( \pm 0.08)$ & 0.81 \\
\hline Mean & 0.92 & 0.69 & 0.80 \\
\hline
\end{tabular}

${ }^{1}$ Subculture and two fungicide concentrations. Data were expressed as mean ( $\left.\pm \mathrm{SE}\right)$. Means followed by equal uppercase letters on the line did not statistically differ from each other, whereas means followed by lowercase letters in the same column did not statistically differ from each other, Duncan's test $(p<0.05)$.

Table 6. Mean values recorded for Bambusa vulgaris explants that survived after 7-days of exposure to the root induction medium added with two activated charcoal concentrations; and to 45 days in mini-incubator system.

\begin{tabular}{ll}
\hline Activated charcoal $\left(\mathrm{g} . \mathrm{L}^{-1}\right)^{1}$ & Survival $(\%)$ \\
\hline 0 & $63.88^{\mathrm{b}}( \pm 7.02)$ \\
1 & $88.88^{\mathrm{a}}( \pm 7.96)$ \\
Mean & 76.38 \\
\hline
\end{tabular}

${ }^{1}$ Data were expressed as mean $( \pm \mathrm{SE})$. Means followed by same letters did not statistically differ from each other, Duncan's test $(p<$ $0.05)$.

The percentage of rooted explants (mean number $=27.77 \%$ ), the number of roots per explant (mean number $=1.50$ roots) and root length per explant (mean length $=2.5 \mathrm{~cm}$ ) did not show significant difference. The survival rate and ex vitro rooting of $B$. vulgaris explants grown in rooting induction medium was higher in plants subjected to mini-incubator than in the ones subjected to acclimatization stages 1 and 2 (Table 7). Only the rooted explants have survived (Figure 3).

Table 7. Survival percentage and ex vitro rooting of Bambusa vulgaris explants exposed to rooting induction medium; based on mini-incubator and acclimatization methods.

\begin{tabular}{lll}
\hline Stage & Survival (\%) & Rooting (\%) \\
\hline Mini-incubator & 76.38 & 27.77 \\
Acclimatization (Stage 1) & 27.77 & 27.77 \\
Acclimatization (Stage 2) & 27.77 & 27.77 \\
\hline
\end{tabular}




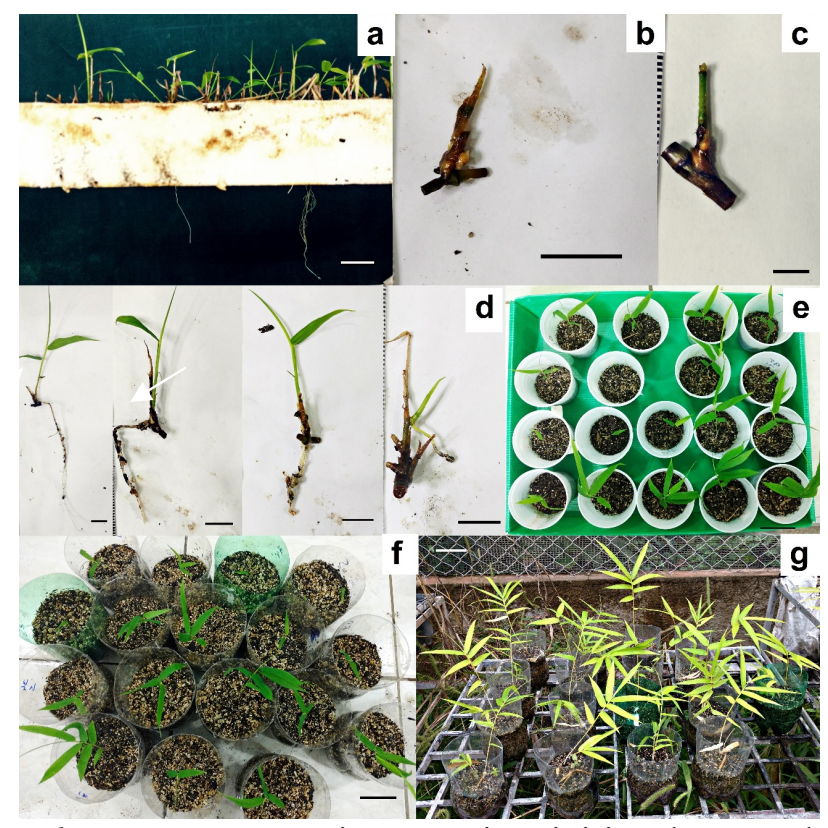

Figure 3. Detail of Bambusa vulgaris ex vitro rooting steps in mini-incubator and acclimatization stages.

(a) Explants after 45 days in mini-incubator (roots under the styrofoam container are easily observed). (b) Dead explant after 45 days in mini-incubator. (c) Surviving explant without root formation after 45 days in mini-incubator. (d) Rooted explants after 45 days in mini-incubator. (e) Surviving plants after the first acclimatization stage. (f) Plants transferred to plastic containers $(500 \mathrm{~mL}) .(\mathrm{g})$ Surviving plants after the second acclimatization stage $(B a r \mathrm{a}, \mathrm{e}-\mathrm{g}=5.0 \mathrm{~cm} ; \mathrm{b}-\mathrm{d}=1.0 \mathrm{~cm})$.

\section{DISCUSSION}

The silvicultural and technological potential of bamboo species has not been properly exploited in Brazil due to the hard time producing clonal plants at commercial scale, among other factors. Given the seed propagation complexity often observed in monocarpic species and in traditional vegetative methods (vegetative propagation), several scholars have succeeded in propagating bamboo species based on in vitro cultivation (SINGH et al., 2012a; ANAND; BRAR; SOOD, 2013; NURHAYANI; MEGIA; PURNAMANINGSIH，2018; SANDHU; WANI; JIMÉNEZ, 2018).

Obtaining viable material during in vitro culture stages depends on several factors such as genotype, physiological state of parent plants, harvest and explant type, asepsis, culture medium (nutrients, vitamins, plant growth regulator concentrations and types), incubation conditions (photoperiod, irradiance and temperature) and operators' ability. For example, the main setback during in vitro establishment lies on fungal and bacterial contamination. Some reports have succeeded in adding fungicides and antibiotics to the culture medium (RIBEIRO et al., 2016; BRONDANI et al., 2017; FURLAN et al., 2018; SANDHU; WANI; JIMÉNEZ, 2018). This strategy was adopted in the present study and it enabled significant microorganism reduction.
Fungi and bacteria are undesirable during in vitro propagation because they can impair explants multiplication and elongation due to competition for nutrients in the culture medium (OLIVEIRA et al., 2015). Thus, it is essential emphasizing several studies aimed at reducing and inhibiting microbial contamination during the micropropagation of several bamboo species such as $B$. vulgaris (RAMANAYAKE; $\quad$ MEEMADUMA; WEERAWARDENE, 2006; TORRES; HOULLOU; DE SOUZA, 2016a; TORRES et al., 2016b; TORRES; LEMOS, 2017), B. bambos (ANAND; BRAR; SOOD, 2013), B. nutans (NEGI; SAXENA, 2011), Guadua angustifolia (JIMÉNEZ et al., 2006; CORREA; MORENO; GONZÁLEZ, 2014), Dendrocalamus asper (SINGH et al., 2012b), D. hamiltonii (SINGH et al., 2012a) and D. strictus (PANDEY; SINGH, 2012). On the other hand, there are groups of endophytic microorganisms that have beneficial relationship with plants. Microorganisms with characteristics capable of helping plant development - either in growth promotion, phytohormone production or in the defense against pathogens - were observed during B. vulgaris in vitro culture (COLETTA et al. 2010; COLETTA et al., 2011).

Fungi incidence (Figure 1A) in the current study may have been caused by several factors such material source (matrices planted in the field, where there is no control over phytosanitary conditions, tend to present higher microorganism contamination 
rate), fungicide type and concentration, as well as endogenous microorganisms (ANDRADE; BAGATIM; JASPER, 2014). The highest fungal contamination rate was observed in explants immersed in fungicide for 72 hours; however, it decreased after 120 hours of exposure (Table 2).

Torres, Houllou and De Souza (2016a) and Torres et al. (2016b) observed lack of bacterial contamination (Figure 1B and Table 1) in culture medium added with antibiotics. Despite the satisfactory results achieved in the aforementioned studies, it is important exercising caution at the time to use such a strategy due to the high cost of the products and the likelihood of phytotoxicity. In addition, antibiotics should be only used for specific contaminants (each antibiotic has an action spectrum). Contaminated material disposal and autoclaving are the most practical solution (TAMBARUSSI et al., 2017).

The reduced survival percentage (Figure 1C and Table 1) resulting from longer exposure to the fungicide can be associated with the action of the product, since, although fungicide addition to the culture medium in in vitro establishment helps controlling contamination, it can have toxic effects on the explant such as growth inhibition and even tissue death (BRONDANI et al., 2013). Although the active principle 5,6-dihydro-2-methyl-1,4oxathi-ine-3-carboxanilide added with tetramethylthiuram disulfide accounted for low mortality rate in the present study, it did not cause phytotoxicity during Butia capitata (SOUZA et al., 2013) and Passiflora edulis (VILLALOBOS; VARGAS; GARCÍA, 2009). This principle results from the combination between systemic and contact fungicides. Systemic fungicides have a selectivity type capable of eradicating and suppressing infections caused by pathogens without damaging host cells. The non-specific mode of action of the contact fungicide, which is highly toxic to plant cells, is what may have led to the death of $B$. vulgaris explants, although at low rate (GARCIA, 1999).

The in vitro establishment phase (Figure 2 and Table 1) can be influenced by several factors such as genetic material, explant type, asepsis method and phytotoxicity, and physiological conditions of mother plants (BRONDANI et al., 2013). Explants from field-planted matrices often present lower establishment percentage than the ones from matrices located in protected sites subjected to nutritional and phytopathological control (BRONDANI et al., 2011). Seasonality is another important factor in micropropagation; and for B. vulgaris, D. giganteus (RAMANAYAKE;
YAKANDAWALA, 1997), D. asper (SINGH et al., 2012b) and D. hamiltonii (SINGH et al., 2012a) has indicated that collection time can influence explant establishment. During the rainy season - when the present study was carried out - shoots collected in fields presented higher microorganism incidence when they were in vitro cultivated (SINGH et al., 2012b).

The increased number of new explants deriving from the shoot section (Table 3) may have suggested hormonal regulator action by the fungicide. The fungicide stimulated shoot multiplication and elongation; consequently, it stimulated new explant formation. Fungicides' action as cell division stimulant was observed in other studies (ANDRADE; BAGATIM; JASPER, 2014). According to Skene (1972), this phenomenon can take place due to changes in the active principle, which result from culture medium autoclaving. Such changes cause the active principle to act as plant growth regulator, however, new experiments must be carried out in order to confirm such action.

Pandey and Singh (2012) have also reported reduced percentage of explants emitting shoots due to longer exposure to germicidal products. These researchers have observed a larger number of shoots after treatment with calcium hypochlorite and mercury chloride, during $D$. strictus in vitro multiplication, although the number of explants emitting shoots reduced when the time of exposure to the products got longer. The highest percentage of explants emitting shoots was recorded in the present study (42.50\% of explants emitting shoots); this outcome corroborates results of experiments conducted with $B$. vulgaris (approximately 40\%) (TORRES et al., 2016b), B. nutans (45\%) (MUDOI; SAIKIA; BORTHAKUR, 2014) and Guadua angustifolia (40\%) (JIMÉNEZ et al., 2006). High percentage of bamboo explants emitting shoots (up to $97 \%$ ) had already been observed by other researchers (GARCÍA-RAMÍREZ et al., 2007; SINGH et al., 2012b; PANDEY; SINGH, 2012; SINGH et al., 2012a; TORRES; HOULLOU; DE SOUZA, 2016a). In these cases, the better results may be associated with inherent characteristics of the matrix plant (SANDHU; WANI; JIMÉNEZ, 2018; ARAÚJO et al., 2019).

The mean number of shoots per explant in the current study could have been higher if it had followed the recommendations by Negi and Saxena (2011) and Pandey and Singh (2012), who found that the use of high cytokinin concentration $\left(5 \mathrm{mg} \mathrm{L}^{-}\right.$

1 of 6-benzylaminopurine - BAP) in the multiplication phase resulted in increased number of B. nutans and D. strictus shoots, respectively. 
However, it is essential highlighting that, to a certain point, increased cytokinin concentrations may be harmful to plants (SINGH et al., 2012a). Devi, Bengyella and Sharma (2012) and Jiménez et al. (2006) observed that high BAP concentrations reduced multiplication in bamboo species (i.e., the number and length of shoots).

Subcultures are another factor positively affecting the number of shoots per explant. In addition to increase shoot rate during multiplication, the promotion of successive subcultures can also restore the juvenile characteristics of adult tissues and favor rooting (SANDHU; WANI; JIMÉNEZ, 2018). Thus, the number of subcultures required during multiplication phase depends on micropropagation goals (BRONDANI et al., 2017).

Mean shoot length was higher in explants treated with fungicide (Table 5), due to its phytoregulatory action (SKENE, 1972; ANDRADE; BAGATIM; JASPER, 2014). The reduction observed in this variable after 30 subculture days may be associated with the increased number of shoots.

The highest survival rate observed in the presence of activated charcoal (Table 6) may be associated with its ability to retain toxic substances found in the culture medium (such as 5hydroxymethyl-furfural, which results from sucrose dehydration during autoclaving) or with inhibitory substances found in the agar, which mitigate the action of toxic metabolites such as phenolic substances, ethylene and abscisic acid, which, in their turn, are eliminated by the explant (SANDHU; WANI; JIMÉNEZ, 2018). Despite the benefits of activated charcoal addition to the culture medium during adventitious rooting (adsorption of toxic or inhibitory substances and reduction of light incidence in the root formation region to stimulate adventitious system formation) (LEITZKE; DAMIANI; SCHUCH, 2009), the presence of this substance was not significant for variables such as rooting, and number and length of roots. Similar results were observed during $D$. hamiltonii rooting (SOOD et al., 2002; SINGH et al., 2012a).

The mean rooting rate observed in the current study was $27.77 \%$. This outcome corroborates the studies by Ramanayake, Meemaduma and Weerawardene (2006) and Ndiaye et al. (2006), who used the same indole-3-butyric acid (IBA) concentrations during $B$. vulgaris rooting. Overall, bamboo species have a hard time in vitro rooting, which makes it difficult to get a large number of explants with roots (MUDOI; SAIKIA; BORTHAKUR, 2014). Auxin addition to the culture medium is of paramount importance to enable rhizogenesis in bamboo plants (LIMA NETO et al., 2010). The absence of this plant growth regulator resulted in lack of rooting in $B$. vulgaris explants (RAMANAYAKE; MEEMADUMA; WEERAWARDENE, 2006). Increased auxin concentrations led to better results during $B$. vulgaris (NDIAYE et al., 2006; RAMANAYAKE; MEEMADUMA; WEERAWARDENE, 2006; MALINI; ANANDAKUMAR, 2013), B. nutans (NEGI; SAXENA, 2011) and D. hamiltonii (SINGH et al., 2012a) rooting.

The mortality of explants that did not show root formation was already expected. The nutrient media used during in vitro culture are responsible for supplying essential substances in order to enable explant growth. However, the formation of functional roots is fundamental for the survival of micropropagated plants subjected to conditions ex vitro. Lack of plant mortality during the acclimatization period suggested functional adventitious root formation. The advantages of ex vitro rooting (directly on the substrate) comprise quality root system formation (which reduces mortality during acclimatization) and reduced micropropagation production costs in comparison to in vitro rooting (SANDHU; WANI; JIMÉNEZ, 2018).

The transfer of explants in vitro grown from humidity and brightness control conditions to greenhouse conditions often implies plant death (BRONDANI et al., 2011). It is important gradually conducting this transfer to assure the survival of plants at acclimatization. The adoption of two acclimatization stages - the first one in a laboratory under controlled temperature, humidity and luminosity conditions, and the second one in a shade house - was efficient in enabling $B$. vulgaris adaptation to ex vitro conditions, which resulted in the survival of all plants (Figure 3 and Table 7).

Briefly, results in the current study have shown that fungicide addition to the culture medium during the establishment reduced fungal contamination, which is a recurrent issue during the establishment of bamboo species, as well as accounted for better results during the multiplication phase. On the other hand, the adoption of culture medium to induce adventitious root formation in the rooting stage, in association with the methodology applied during the acclimatization, provided interesting results. The methodology proposed in the present study enabled generating a protocol aimed at forming clonal samplings of $B$. vulgaris suitable to be used in several forest chain sectors.

$B$. vulgaris explant immersion in liquid culture media added with $1 \mathrm{~mL} \mathrm{~L}^{-1}$ of fungicide for 
120 hours resulted in the lowest fungal contamination and in the highest percentage of established explants. Explants immersed in liquid culture medium added with $1 \mathrm{~mL} \mathrm{~L}^{-1}$ of fungicide for 120 hours in the in vitro multiplication presented the best results for shoot emission rate and mean number of shoots per explant. Furthermore, the presence of activated charcoal in the culture medium, during ex vitro rooting, resulted in increased plant survival. Finally, the use of two different acclimatization stages - the first one under controlled temperature, luminosity and humidity conditions and the second one in the shade-house - was efficient in enabling the adaptation and survival of clonal plants under ex vitro conditions.

\section{ACKNOWLEDGMENTS}

To the National Counsel of Technological and Scientific Development (Conselho Nacional de Desenvolvimento Científico e Tecnológico - CNPq), Coordination for Improvement of Higher Education Personnel (Coordenação de Aperfeiçoamento de Pessoal de Nível Superior - CAPES), and Foundation for Research of the State of Minas Gerais (Fundação de Amparo a Pesquisa do Estado de Minas Gerais - FAPEMIG).

RESUMO: As espécies de bambus são uma alternativa para a composição de plantios florestais. Entretanto, esse potencial não tem sido explorado devido à dificuldade de produção de mudas clonais em larga escala. Assim, objetivo deste trabalho foi avaliar o estabelecimento in vitro, a multiplicação e o enraizamento ex vitro de Bambusa vulgaris. No primeiro experimento foram testadas diferentes soluções de fungicida sistêmico e de contato em relação ao tempo de exposição durante a fase de estabelecimento. Os explantes estabelecidos foram avaliados quanto ao efeito residual do fungicida durante subcultivos nas fases de multiplicação e alongamento. No segundo experimento, foi avaliada a influência do carvão ativado sobre a sobrevivência e enraizamento ex vitro. Durante o estabelecimento in vitro, a imersão de explantes em meio de cultura líquido contendo alíquota de $1,0 \mathrm{~mL}$ de fungicida durante 120 horas favoreceu o estabelecimento e reduziu a contaminação fúngica, enquanto na fase de multiplicação, houve o favorecimento da emissão de brotos por explante. O meio de cultura de indução ao enraizamento e uso de sistema de mini-estufim foram efetivos para a formação de raízes adventícias e a presença de carvão ativado resultou em uma maior sobrevivência das mudas clonais.

PALAVRAS-CHAVE: Bambusa vulgaris. Clonagem. Estabelecimento in vitro. Micropropagação. Multiplicação. Enraizamento adventício.

\section{REFERENCES}

AFONSO, D. G.; SILVA, Z. A. G. P. G. Bambu nativo: alternativa de desenvolvimento econômico e sustentável para o estado do Acre. In: DRUMOND, P.; WIEDMAN, G. (Orgs.). Bambus no Brasil: da biologia à tecnologia. 1. ed. Rio de Janeiro: Instituto Ciência Hoje, 2017. p. 290-306.

ANAND, M.; BRAR, J.; SOOD, A. In vitro propagation of an edible bamboo Bambusa bambos and assessment of clonal fidelity through molecular markers. Journal of Medical and Bioengineering, v. 2, n. 4, p. 257-261, 2013. doi: 10.12720/jomb.2.4.257-261

ANDRADE, R. A.; BAGATIM, A. G.; JASPER, S. P. Soursop contamination and sprouting in function of the fungicide in the culture medium. Comunicata Scientiae, v. 5, n. 3, p. 326-330, 2014.

ARAÚJO, E. F.; GIBSON, E. L.; SANTOS, A. R.; GONÇALVES, E. O.; WENDLING, I.; ALEXANDRE, R. S.; POLA, L. A. V. Mini-cutting technique for vegetative propagation of Paratecoma peroba. Cerne, v. 25 , n. 3, p. 314-325, 2019. doi: 10.1590/01047760201925032647

BRONDANI, G. E.; DUTRA, L. F.; WENDLING, I.; GROSSI, F.; HANSEL, F. A.; ARAUJO, M. A. Micropropagation of an Eucalyptus hybrid (Eucalyptus benthamii $\times$ Eucalyptus dunnii). Acta Scientiarum. Agronomy, v. 33, n. 4, p. 655-663, 2011. doi: 10.4025/actasciagron.v33i4.8317 
BRONDANI, G. E.; OLIVEIRA, L. S.; BERGONCI, T.; BRONDANI, A. E.; FRANÇA, F. A. M.; SILVA, A. L. L.; GONÇALVES, A. N. Chemical sterilization of culture medium: a low cost alternative to in vitro establishment of plants. Scientia Forestalis, v. 41, n. 98, p. 257-264, 2013.

BRONDANI, G. E.; OLIVEIRA, L. S.; FURLAN, F. C.; RIBEIRO, A. S. Estabelecimento in vitro de Bambusa vulgaris Schrad. ex J. C. Wendl e Dendrocalamus asper (Schult. \& Schult. F.) Backer ex K. Heyne. In: DRUMOND, P.; WIEDMAN, G. (Orgs.). Bambus no Brasil: da biologia à tecnologia. 1. ed. Rio de Janeiro: Instituto Ciência Hoje, 2017. p. 86-102.

BRONDANI, G. E.; OLIVEIRA, L. S.; KONZEN, E. R.; SILVA, A. L. D.; COSTA, J. L. Mini-incubators improve the adventitious rooting performance of Corymbia and Eucalyptus microcuttings according to the environment in which they are conditioned. Anais da Academia Brasileira de Ciências, v. 90, n. 2, suppl. 1, p. 2409-2423, 2018. doi: 10.1590/0001-3765201720170284

CALEGARI, L.; HASELEIN, C. R.; LORI SCARAVELLI, T.; SANTINI, É. J.; MARTINS STANGERLIN, D.; GATTO, D. A.; TREVISAN, R. Desempenho físico-mecânico de painéis fabricados com bambu (Bambusa vulgaris Schr.) em combinação com madeira. Cerne, v. 13, n. 1, p. 57-63, 2007.

COLETTA, R.; GOMES, J.E; ROSSI, M.L; OLIVEIRA, E.T.; TSAI, S.M.; CALDAS, D.G.C.; Caracterização molecular de bactérias endofíticas em explantes micropropagados de bambu. In: Simpósio Internacional de Iniciação Científica e Tecnológica da USP, 2010, Piracicaba. Anais... Piracicaba: USP, 2011.

COLETTA, R. D.; GOMES, J. E.; TSAI, S. M.; CALDAS, D. G. G. Análise comparativa entre endofíticos de bambu em biorreatores de imersão temporária e explantes cultivados in vitro através do sequenciamento do $16 \mathrm{~S}$ rRNA. In: Simpósio Internacional de Iniciação Científica e Tecnológica da USP, 2011, Piracicaba. Anais... Piracicaba: USP, 2011.

CORREA, L. A. R.; MORENO, J. E. G.; GONZÁLEZ, N. E. C. Evaluación del efecto de tratamientos de desinfección con hipoclorito de sodio sobre segmentos nodales de Guadua angustifolia Kunth para el establecimiento del cultivo in vitro. Revista de Investigación Agraria y Ambiental, v. 5, n. 1, p. 155-169, 2014. https://doi.org/10.22490/21456453.944

DA MOTA, I. D. O.; PEREIRA, M. A; DAMACENA, P. C.; DOS SANTOS, L. C. B. Estudo das propriedades físicas e mecânicas do bambu brasileiro (Bambusa vulgaris vittata) para aplicação na construção de sistemas hidráulicos alternativos de distribuição de água à baixa pressão. Revista de Estudos Ambientais, v. 19, n. 1, p. 18-26, 2017. doi: 10.7867/1983-1501.2017v19n1p18-26

DEVI, W. S.; BENGYELLA, L.; SHARMA, G. J. In vitro seed germination and micropropagation of edible bamboo Dendrocalamus giganteus Munro using seeds. Biotechnology, v. 11, n. 2, p. 74-80, 2012. doi: 10.3923/biotech.2012.74.80

DO VAlE, A. T.; MOREIRA, A. C. O; MARTINS, I. S. Avaliação do potencial energético de Bambusa vulgaris em função da idade. Floresta e Ambiente, v. 24, e00123314, 2017. doi: 10.1590/2179-8087.123314.

ERIG, A. C.; SCHUCH, M. W. Micropropagação fotoautotrófica e uso da luz natural. Ciência Rural, v. 35, n. 4, p. 961-965, 2005. doi: 10.1590/S0103-84782005000400039

FURLAN, F. C.; GAVILAN, N. H.; ZORZ, A. Z.; OLIVEIRA, L. S.; KONZEN, E. R.; BRONDANI, G. E. Active chlorine and charcoal affect the in vitro culture of Bambusa vulgaris. Bosque, v. 39, n. 1, p. 61-70, 2018. doi: 10.4067/S0717-92002018000100061

GARCIA, A. Fungicidas I: utilização no controle químico de doenças e sua ação contra os fitopatógenos. Porto Velho: EMBRAPA-CPAF Rondônia, 1999. 32 p. (EMBRAPA-CPAF Rondônia. Documentos, 46). 
GARCÍA-RAMÍREZ, Y. G; FREIRE-SEIJO, M.; FAJARDO, L.; TEJEDA, M.; REYES, M. Establecimiento in vitro de yemas axilares de Bambusa vulgaris var Vittata. Biotecnología Vegetal, v. 7, n. 3, p. 155-159, 2007.

GARCÍA-RAMÍREZ, Y. G.; SEIJO, M. F.; PÉREZ, B. R.; HURTADO, O. Establecimiento in vitro de Bambusa vulgaris var. vulgaris Schrad. ex. Wendl. en diferentes épocas del año. Biotecnología Vegetal, v. 10, n. 3, p. 151-156, 2010.

GUIMARÃES JÚNIOR, M.; NOVACK, K. M.; BOTARO, V. R. Caracterização anatômica da fibra de bambu (Bambusa vulgaris) visando sua utilização em compósitos poliméricos. Revista Iberoamericana de Polímeros, v. 11, n. 7, p. 442-456, 2010.

JIMÉNEZ, V. M.; CASTILLO, J.; TAVARES, E.; GUEVARA, E.; MONTIEL, M. In vitro propagation of the neotropical giant bamboo, Guadua angustifolia Kunth, through axillary shoot proliferation. Plant Cell, Tissue and Organ Culture, v. 86, n. 3, p. 389-395, 2006. doi: 10.1007/s11240-006-9120-4

LEITZKE, L. N.; DAMIANI, C. R.; SCHUCH, M. W. Multiplicação e enraizamento in vitro de amoreira-preta 'Xavante': efeito da concentração de sais, do tipo de explante e de carvão ativado no meio de cultura. Ciência e Agrotecnologia, v. 33, n. spe, p. 1959-1966, 2009. doi: 10.1590/S1413-70542009000700045

LIMA NETO, M. C.; BEZERRA NETO, E.; BARRETO, L. P.; DA SILVA, J. A. Exportação de macronutrientes em cultivos comerciais de bambu no tabuleiro costeiro do Estado da Paraíba. Revista Árvore, v. 34 , n. 2 , p. 251-257, 2010. doi: 10.1590/S0100-67622010000200007

MALINI, N.; ANANDAKUMAR, C. R. Micropropagation of bamboo (Bambusa vulgaris) through nodal segment. International Journal of Forestry and Crop Improvement, v. 4, n. 1, p. 36-39, 2013.

MENDES, S. C.; MOLICA, S. G.; FERREIRA, R. L. C.; CÉSPEDES, G. H. G. Absorção e distribuição de nutrientes em plantios comerciais de bambu (Bambusa vulgaris) no nordeste do Brasil. Revista Árvore, v. 34 , n. 6, p. 991-999, 2010. doi: 10.1590/S0100-67622010000600004

MOGNON, F.; SANQUETTA, C. R.; DALLA CORTE, A.; RODRIGUES, A. L.; SANQUETTA, M. N. I. Bambu, uma alternativa para o sequestro de carbono. In: DRUMOND, P.; WIEDMAN, G. (Orgs.). Bambus no Brasil: da biologia à tecnologia. 1. ed. Rio de Janeiro: Instituto Ciência Hoje, 2017. p. 227-241.

MUDOI, K. D.; SAIKIA, S. P.; BORTHAKUR, M. Effect of nodal positions, seasonal variations, shoot clump and growth regulators on micropropagation of commercially important bamboo, Bambusa nutans Wall. ex. Munro. African Journal of Biotechnology, v. 13, n. 19, p. 1961-1972, 2014. doi: 10.5897/AJB2014.13659

NDIAYE, A.; DIALLO, M. S.; NIANG, D.; GASSAMA-DIA, Y. K. In vitro regeneration of adult trees of Bambusa vulgaris. African Journal of Biotechnology, v. 5, n. 13, p. 1245-1248, 2006.

NEGI, D.; SAXENA, S. In vitro propagation of Bambusa nutans Wall. ex Munro through axillary shoot proliferation. Plant Biotechnology Reports, v. 5, n. 1, p. 35-43, 2011. doi: 10.1007/s11816-010-0154-z

NURHAYANI, S.; MEGIA, R.; PURNAMANINGSIH, R. In vitro propagation of Bambusa balcooa as alternative material of wood. Biosaintifika: Journal of Biology \& Biology Education, v. 10, n. 1, p. 198-204, 2018. doi: 10.15294/biosaintifika.v10i1.11079

OLIVEIRA, L. S.; BRONDANI, G. E.; BATAGIN-PIOTTO, K. D.; CALSAVARA, R.; GONÇALVES, A. N.; ALMEIDA, M. Micropropagation of Eucalyptus cloeziana mature trees. Australian Forestry, v. 78, n. 4, p. 219-231, 2015. doi: 10.1080/00049158.2015.1073211

PANDEY, B. N.; SINGH, N. B. Micropropagation of Dendrocalamus strictus nees from mature nodal explants. Journal of Applied and Natural Science, v. 4, n. 1, p. 5-9, 2012. doi: 10.31018/jans.v4i1.213 
RAMANAYAKE, S. M. S. D.; YAKANDAWALA, K. Micropropagation of the giant bamboo (Dendrocalamus giganteus Munro) from nodal explants of field grown culms. Plant Science, v. 129, v. 2, p. 213-223, 1997. doi: 10.1016/S0168-9452(97)00185-4

RAMANAYAKE, S.; MEEMADUMA V.; WEERAWARDENE T. In vitro shoot proliferation and enhancement of rooting for the large-scale propagation of yellow bamboo (Bambusa vulgaris 'Striata').

Scientia Horticulturae, v. 110, n. 1, p. 109-113, 2006. doi: 10.1016/j.scienta.2006.06.016

RAMÍREZ, Y. G.; FREIRE-SEIJO, M.; MEDEROS, B. R.P.; RIVALTA, H. Effect of IBA and TDZ on in vitro rooting of plants Bambusa vulgaris var. vulgaris Schrad. ex Wendl. Revista Colombiana de Biotecnología, v. 14, n. 1, p. 200-207, 2012.

RIBEIRO, A. S.; BRONDANI, G. E., TORMEN, G. C. R., FIGUEIREDO, A. J. R. Cultivo in vitro de bambu em diferentes sistemas de propagação. Nativa, v. 4, n. 1, p. 15-18, 2016. doi: 10.14583/2318-7670.v04n01a04

SANDHU, M.; WANI, S. H.; JIMÉNEZ, V. M. In vitro propagation of bamboo species through axillary shoot proliferation: a review. Plant Cell, Tissue and Organ Culture, v. 132, n. 1, p. 27-53, 2018. doi:

$10.1007 / \mathrm{s} 11240-017-1325-1$

SINGH, S. R.; DALAL, S.; SINGH, R.; DHAWAN, A. K.; KALIA, R. K. Seasonal influences on in vitro bud break in Dendrocalamus hamiltonii Arn. ex Munro nodal explants and effect of culture microenvironment on large scale shoot multiplication and plantlet regeneration. Indian Journal of Plant Physiology, v. 17, n. 1, p. 9-21, 2012a.

SINGH, S. R.; DALAL, S.; SINGH, R.; DHAWAN, A. K.; KALIA, R. K. Micropropagation of Dendrocalamus asper \{Schult. e Schult. F. B Backer ex K. Heyne): an exotic edible bamboo. Journal of Plant Biochemistry and Biotechnology, v. 21, n. 2, p. 220-228, 2012b. doi: 10.1007/s13562-011-0095-9

SKENE, K. G. M. Cytokinin-like properties of the systemic fungicide benomyl. Journal of Horticultural Science, v. 47, n. 2, p. 179-182, 1972. doi: 10.1080/00221589.1972.11514454

SOOD, A.; AHUJA, P. S.; SHARMA, M.; SHARMA, O. P.; GODBOLE, S. In vitro protocols and field performance of elites of an important bamboo Dendrocalamus hamiltonii Nees et Arn. ex Munro. Plant Cell, Tissue and Organ Culture, v. 71, n. 1, p. 55-63, 2002. doi: 10.1023/A:1016582732531

SOUZA, A. Í. R. C.; NEVES, S. C.; SILVA, P. O.; ANDRADE, I. G.; RIBEIRO, L. M.; LOPES, P. S. N. Efeito de fungicidas no cultivo in vitro de embriões de coquinho-azedo. Revista Unimontes Científica, v. 15, n. 2, p. 1-7, 2013.

TAMBARUSSI, E. V.; ROGALSKI, M.; GALEANO, E.; BRONDANI, G. E.; MARTIN, V. F.; SILVA, L. A.; CARRER, H. Efficient and new method for Tectona grandis in vitro regeneration. Crop Breeding and Applied Biotechnology, v. 17, n. 2, p. 124-132, 2017. doi: 10.1590/1984-70332017v17n2a19

TORRES, G. R. C.; HOULLOU, L. M.; DE SOUZA, R. A. Control of contaminants during introduction and establishment of Bambusa vulgaris in vitro. Research in Biotechnology, v. 7, p. 58-67, 2016a. doi: 10.19071/rib.2016.v7.3056

TORRES, G. R.; SANTOS, P. V. S.; SOUZA, R. A.; DANTAS, P. V. P. Efeito da posição de segmentos nodais sobre a contaminação e brotação na micropopagação do bambu. Ciência \& Tecnologia: Fatec-JB, v. 8 , n. 1, p. 1-15, 2016 b.

TORRES, G. R.; LEMOS, E. E. P. Physical and chemical methods for contaminant control during the in vitro introduction and establishment of Bambusa vulgaris Schrad. ex JC Wendl. Científica, v. 45, n. 4, p. 368-378, 2017. doi: 10.15361/1984-5529.2017v45n4p368-378

VILLALOBOS, M. R.; VARGAS, T. E.; GARCÍA, E. Cultivo de microesquejes de parchita (Passiflora edulis Sims f. flavicarpa Deg.). Revista Científica UDO Agrícola, v. 9, n. 2, p. 327-332, 2009. 